IZA DP No. 9886

Why Do Some Young Adults Not Graduate from Upper Secondary School? On the Importance of Signals of Labour Market Failure

Björn Gustafsson

Katarina Katz

Torun Österberg

April 2016 


\title{
Why Do Some Young Adults Not Graduate from Upper Secondary School? On the Importance of Signals of Labour Market Failure
}

\author{
Björn Gustafsson \\ University of Gothenburg and IZA \\ Katarina Katz \\ Karlstad University \\ Torun Österberg \\ University of Gothenburg
}

Discussion Paper No. 9886

April 2016

IZA

P.O. Box 7240

53072 Bonn

Germany

Phone: +49-228-3894-0

Fax: +49-228-3894-180

E-mail: iza@iza.org

\begin{abstract}
Any opinions expressed here are those of the author(s) and not those of IZA. Research published in this series may include views on policy, but the institute itself takes no institutional policy positions. The IZA research network is committed to the IZA Guiding Principles of Research Integrity.

The Institute for the Study of Labor (IZA) in Bonn is a local and virtual international research center and a place of communication between science, politics and business. IZA is an independent nonprofit organization supported by Deutsche Post Foundation. The center is associated with the University of Bonn and offers a stimulating research environment through its international network, workshops and conferences, data service, project support, research visits and doctoral program. IZA engages in (i) original and internationally competitive research in all fields of labor economics, (ii) development of policy concepts, and (iii) dissemination of research results and concepts to the interested public.
\end{abstract}

IZA Discussion Papers often represent preliminary work and are circulated to encourage discussion. Citation of such a paper should account for its provisional character. A revised version may be available directly from the author. 
IZA Discussion Paper No. 9886

April 2016

\section{ABSTRACT}

\section{Why Do Some Young Adults Not Graduate from Upper Secondary School? On the Importance of Signals of Labour Market Failure}

In high-income countries, not completing secondary school often entails a high risk of social exclusion. Using data on young adults born in 1985 that grew up in metropolitan Sweden, we study factors associated with not graduating from upper secondary school at age 21 . Our hypothesis is that if a young person sees examples of people who are not able to earn a living despite having a long education, such negative examples are influential. Results from estimated logistic models are consistent with the hypothesis.

JEL Classification: D64, 124, R23

Keywords: $\quad$ secondary schooling, Sweden, social exclusion, neighbourhoods

Corresponding author:

Björn Gustafsson

Department of Social Work

University of Gothenburg

P.O. Box 720

SE 40530 Gothenburg

Sweden

E-mail: Bjorn.Gustafsson@socwork.gu.se 


\section{Introduction}

This paper investigates factors associated with whether men and women born in 1985, who grew up in metropolitan Sweden, had graduated from upper secondary school at age 21 . The issue is important since, for the generation under study, a short education is very often seen to entail a risk of social exclusion. In Sweden, approximately one out of six young adults in a birth cohort does not complete upper secondary school. However, the proportion of 21-yearolds without upper secondary school education varies substantially across metropolitan neighbourhoods from practically zero to as many as four out of ten, see Figure 1.

/Figure 1 about here/

It is usually considerably more difficult for persons without a complete upper secondary education to find and keep a job than for their peers with longer education. As a result, they are at high risk of receiving unemployment compensation and/or social assistance. Furthermore, a short education is often correlated with ill health as well as with nonparticipation in societal activities. At the policy level, awareness of this is shown by the fact that completion of upper secondary school has been brought forward in discussion and formulation of indicators of social inclusion within the European Union and in the design of measures. ${ }^{1}$

Why have some young adults not graduated from upper secondary school? One way to approach this question is to focus on the young people themselves. Low learning skills and low learning motivation and - hence - low academic achievements are central explanatory factors when such an approach is taken. Alternatively, the analysis can focus on the parents; their human capital, support and expectations. Parents, who have short education themselves, often have less capacity to assist and encourage learning by their children, and are not role models when it comes to choosing higher-level education. A third approach is to focus on schools. Some schools provide better environments for learning and personal development than others. This can be because of how schools are run, teaching quality, teacher/student ratios, physical resources as well as the level of knowledge and motivation among pupils. Regulations and allocation of resources to different schools are ways in which politicians can influence learning in school and thereby the numbers who will complete upper secondary school. Reasons for not completing upper secondary school can thus be framed as failure by 
the individual, failure by parents, failure by schools, as well as failures in education policies and their implementation.

While recognizing that each of these approaches contributes to the understanding of why some young adults do not graduate from upper secondary school, this paper proposes yet another frame of explanation. We show that it can be fruitful to focus on the labour market success or failure of "relevant adults" surrounding the young person within as well as outside the immediate family. For some young persons, graduating from upper secondary school may not appear as a sufficiently attractive option to be worth the effort. This can be the case if, in the environment in which they live, they observe adults who have acquired a long education but are nevertheless not able to support themselves. Relatives, as well as persons in the neighbourhood where the young person lives, can be such discouraging examples.

There are a number of studies showing that immigrant parents tend to have high aspirations for the education of their children but also studies indicating that these aspirations are often thwarted (for references on both counts, see Salikutluk, 2013). The mechanism we point to may be one among the reasons for this so-called "aspiration-achievement paradox". A similar, apparently paradoxical, lack of congruence between a high value ascribed to education and low educational achievement had long been noted among young Afro-americans. It was explained by Ogbu (1978), and a whole research tradition taking its starting point in his work, as a rational reaction to the knowledge that African American students have of discrimination in the labour market.. For example, Mickelson (1990) found that black high school students achievement in high school was significantly negatively affected if they believed that education would not give them as African Americans the same labour market opportunities as it would give white students.

Qualitative research in Sweden has indicated that young people from economically disadvantaged neighbourhoods with high concentrations of immigrants often express a sense of stigmatization - that prospective employers and others in positions of authority will discriminate against them when it is known where they live. (For examples, see Hertzberg, 2003, Bunar, 2011 and Widgison, 2013). An issue to explore through qualitative research is whether unemployment in the neighbourhood, particularly of the highly educated, reinforces that sense of stigmatization and the feeling that "there is no point" in studying. 
An example of such research is an ethnographic study in which pupils in a marginalized neighbourhood were interviewed:

Young people in the marginalized neighbourhoods in which we have done our research generally (with a few exceptions) do not believe they have the same opportunities as Swedes and pupils from other schools in other areas do, nor do they seem to have these opportunities. They are and they know that they are discriminated against on the labour market as well as on the housing market, and they are and know they are harassed and treated differently by the police and looked at differently when they enter fashionable high-street stores. ... At an early age these young people develop a perception of themselves as subordinate and as not belonging. This is not actually done only or perhaps even primarily through the schools. (Beach \& Sernhede, 2011, p. 269)

A motivation behind our quantitative analysis is to see whether the results are such as could be expected from these qualitative studies or whether they would contradict them.

We have found it thought-provoking to connect what Beach and Sernhede found in Swedish outer cities and the US studies mentioned above. Certainly, the analogy should not be drawn too far although there are similarities between underprivileged and stigmatized neighbourhoods, with high concentrations of immigrants on the outskirts of European cities and the black ghettoes of American inner cities, the institutional, political and historical contexts are very different (Wacquant, 2008).. This does not preclude that young persons who experience social exclusion in Europe and the US could react in similar ways.

Register data do not allow us to access attitudes directly. Yet having adults in the neighbourhood whose experience indicates a poor reward from education appears to play a role for educational behaviour reminiscent of that of opinions such as "People in my family haven't been treated fairly at work no matter how much education they have" or "Studying in school rarely pays off later with good jobs" did for the young African Americans interviewed by by Mickelson (1990).

Results from the present study suggest that such a mechanism can play a remarkably important role. We study the entire cohort of persons born in 1985, who grew up in metropolitan Sweden, and investigate the probability that they have completed upper secondary school at age 21 . We pay particular attention to children of immigrants since 
among these a large proportion has not completed upper secondary school at age 21 (see Table 1). At the parental level, we focus on whether the probability that young adults do not graduate from upper secondary school is related to having parents who are unable to support themselves through work even though they have had a long education. We also relate the probability of not having completed secondary school to the proportion of persons who live in the same neighbourhood as the young persons, and are not able to support themselves through work, despite a long education. In the statistical analysis we also include a number of controls that have been shown to be related to the length of schooling in earlier studies, including parental education, parental income and immigrant background.

The rest of the paper is structured as follows: The next section gives a brief literature overview, with emphasis on Swedish studies. Section 3 describes the institutional context, Section 4 reports and discusses the design of the study and Section 5 presents the neighbourhood definition we are working with. Relative frequencies of not having graduated from secondary school are reported in Section 6 where the results of the statistical analysis are summarized. Section 7 summarizes the paper.

\section{Families, neighbourhoods and educational outcomes}

Over more than a century, social scientists have investigated links between parental background and the educational attainment of their offspring. ${ }^{2}$ Rational choice frameworks have been used for understanding educational choices. ${ }^{3}$ Another strand of literature asks whether the neighbourhood where a young person grows up influences his or her future education, beyond the influence of individual and family characteristics. Albeit large and growing, this body of literature is more recent and we therefore treat it in more detail. The mechanism behind a "neighbourhood effect" could be school quality, or interaction with peers. Most studies find significant peer effects on educational achievement. ${ }^{4}$ Children interact with each other in school. Yet not only peers but also the experience of "relevant adults" outside the immediate family could influence adolescents, as role models, through social control and by transmission of habits and skills. 
Sanbonmatsu et al. (2009) follow children from the US Moving to Opportunity project where families were randomly selected for rehousing in more affluent neighbourhoods. They find no, or small, effects on test scores in maths or reading skills. Several other US studies, however, do find effects. ${ }^{5}$ More relevant for our study, are those made in a more similar institutional context, such as the Dutch study by Sykes and Kuyper (2009), ${ }^{6}$ which do find a negative relation between neighbourhood socio-economic disadvantage and educational outcomes of children.

In Sweden, Lindahl (2011) finds that for a sample born in 1953 there are neighbourhood correlations in educational outcomes, but results are considerably weaker than the sibling correlations. For a cohort born around 1985, Brännström (2008) reports that although neighbourhoods matter for the variance in education achievement, characteristics attributed to upper secondary school matter much more. Hällgren and Szulkin (2009) and Lindvall (2009) find relations between neighbourhood socio-economic characteristics and educational outcomes, but these are smaller than those of parental characteristics or sibling correlations. Andersson and Subramanian (2006) found very small effects of either parental or average neighbourhood income on length of education but both parents' education and proportion with higher education in the neighbourhood, as well as proportion receiving social assistance, had sizeable predictive power. Andersson and Malmberg (2015) report in a similar study that the strength of the estimated contextual effects increase substantially when statistics based on scalable individualized neighbourhoods are used to measure context.

Several studies investigate educational achievements among immigrant children in Sweden. One example is Jonsson and Szulkin (2007) who analyse ethnic segregation and school achievements of the children of immigrants, discuss different putative mechanisms and review earlier literature. Bygren and Szulkin (2010) find that, for immigrant children, to live in a neighbourhood with many immigrants from the same region, affects their educational attainment negatively if adult "co-ethnics" have low education and children of the same background do badly in school, but not otherwise. Åslund et al. (2009) use the placement policy applied in Sweden in 1987-91, whereby refugees granted residence were allocated to municipalities instead of self-selecting into neighbourhoods, as a pseudo-experimental setting. They find a positive effect on school grades of having highly educated co-ethnics in the neighbourhood. Grönqvist (2006) finds that children of non-Western immigrants are less 
likely to graduate from higher education if they live in a municipality with many such immigrants.

The adults that a young person knows, or knows of, are an important source of information for what they expect education to lead to. Hällgren and Szulkin (2009) note that young people in economically disadvantaged neighbourhoods see many examples of adults, mostly nonWestern immigrants, who despite educational qualifications cannot find work, or work corresponding to their education and that this may lead them to expect little benefits from education. This in turn could result in lower effort and commitment in school.

One Swedish study that does attempt to assess the relation between the economic returns to education of adults in the neighbourhood and the educational choices of teenagers is that of Lindvall (2009). He estimates the probability that a 16-year-old will choose an upper secondary school programme which makes students eligible for university studies, controlling for individual and parental characteristics and predicted earnings differentials according to education. The last are imputed from neighbourhood-specific estimated earnings regressions and significantly increase the probability of choosing such a programme.

Our study differs from the others that we are aware of in several respects. The outcome that we focus on is not having completed upper secondary school, rather than years of schooling, or school grades, as has been done in most previous research. As explanatory variables we use the presence of adults in the parental home, as well as in the neighbourhood, who have had a relatively long education but who have not been successful in the labour market. Furthermore, we work with a definition of neighbourhood that has been developed for research purposes.

\section{The Swedish context}

The Swedish schools system has undergone substantial changes since the parents of the cohort we study (persons born in 1985) attended school and also since the time when the studied cohort itself started school. In the beginning of the 1990s the headship of primary and secondary schools in Sweden was transferred from central government to local government (the municipalities), most likely giving scope for more local variation. At approximately the same time, students and their parents were given the right to choose schools freely. Parallel to 
this, private for-profit firms were allowed to establish schools and admit students, subject to approval by the Schools Inspectorate. From then on, the proportion of each birth cohort that attends a school run by a local authority has gradually decreased, particularly in the metropolitan areas. However, Swedish schools at all levels continue to be publicly funded and tuition is free. ${ }^{7}$

In Sweden children are typically required to start school in August during their seventh year and attend nine years of compulsory schooling (grundskola). They typically enter upper secondary school in the year that they turn 16. In upper secondary school (gymnasium) there is a choice between several different programmes. Competition for admission to a programme is decided by grades achieved in compulsory school. Some programmes are "Academic" and provide general education with a (broad) orientation such as "Science" or "Social Science". "Vocational" programmes provide specific training for occupations such as construction worker or assistant nurse. When the cohort studied here went to upper secondary school the length of all programmes was three years and all gave access to higher education. This means that most of them graduated from secondary school in the year they turned 19, and a few at a somewhat higher age.

Due to relatively large immigration, Sweden is a far more ethnically diverse country today than it was half a century ago. Immigrants have arrived from many different countries and for different reasons. Many have arrived as refugees or as families of refugees. Disproportionally many immigrants live in the metropolitan regions. According to our data, of persons who were born in 1985 and who grew up in metropolitan Sweden, not less than 25 per cent had parents who were both were born abroad.

It is well known that many categories of immigrants to Sweden have difficulty gaining entry into the labour market and that a considerable number do not find jobs which correspond to their education. How to change this is a focus for policy discussion. ${ }^{8}$ This is particularly the case for newly arrived immigrants and for persons originating in low and middle income countries who often are "visibly different" from the majority. Most likely many circumstances have contributed to this. Average education differs very much between immigrant groups. In some it is as high as, or higher than, education among the native born. In some others there is a large proportion with very short schooling, and, generally, in Sweden there are rather few job openings for workers who do not have completed upper 
secondary education. Limitations in the transferability of human capital and language skills in particular, may be another set of significant factors. In addition, many immigrants do not have the same access to networks that are useful for finding a job. Convincing evidence indicates that potential employers discriminate against job applicants who appear to be of non-Western origin. ${ }^{9}$ Furthermore, collective bargaining has resulted in comparably high minimum wages. It may be the case that in a hypothetical situation with lower minimum wages, a higher proportion of immigrants would have been working.

Since the first half of the 1990s income inequality in Sweden has been increasing and housing policy has radically changed towards market-governed housing provision with much less public sector involvement. ${ }^{10}$ Parallel to - and as a consequence of - this, residential segregation has increased in metropolitan Sweden. ${ }^{11}$ As a result of these processes, a disproportionately large number of young persons with an immigrant background grow up with parents who cannot support their families through paid work, and live in neighbourhoods with relatively large numbers of adults who do not find a job despite a long education.

\section{Research design}

We study all individuals who were born in 1985 and who lived in one of Sweden's three metropolitan areas in 2001. The Stockholm metropolitan region includes 24 municipalities (city level units) on the east coast and has the largest population. The Gothenburg metropolitan region on the west coast of Sweden is the second largest in terms of population size and includes eight municipalities. The metropolitan region with the smallest population size consists of the city of Malmö and eight neighbouring municipalities in the south of Sweden.

The individual data we work with comes from the database LISA (Longitudinell integrationsdatabas för Sjukförsäkrings- och Arbetsmarknadsstudier, in English Longitudinal Integrated Database for Health Insurance and Labour Market Research) plus information on each individual's matching neighbourhood codes. Statistics Sweden (2011) documents the database LISA which uses personal identity numbers of all persons permanently residing in 
Sweden in order to link information across registers and years. For this study we have extracted a dataset covering all individuals who were born in 1985 and who lived in one of the three metropolitan areas in 2001 as well as their parents. The latest entries in the database we work with are from 2006, when the cohort we are studying turned 21 . We follow all those who remained anywhere in Sweden until 2006. Thus, the only attrition is a very small number of persons who have died or emigrated.

/Table 1 about here/

Table 1 describes characteristics of the households and neighbourhoods in which the young men and women in the study lived in 2001. All information on the parental households used in our models refers to this year. Parents are identified when registered at the same address as the child. We can identify if there is one adult male in the household and the number of children in the household. For the young adults and their parents we obtained information on demographic variables like year of birth, country of birth and years since immigration which LISA had obtained from the population register. Information on the level of education for both generations originates from the register of education which includes detailed administrative records of education completed in Sweden and information on education received outside Sweden obtained from questionnaires or validated certificates. We have defined dummy variables for three levels of parental education based on the parent with the highest level of education, plus a variable indicating that no information on education is available.

The income information includes variables measuring various components of disposable income: Earnings, capital income and transfers, defined net of income tax. This information originates from the Swedish Income and Tax register, which in turn receives its information from the tax authority and various authorities paying transfers to the households. We use the disposable household income in 2001 and income quartile refers to equivalent disposable income of all Swedish households that included a child born in $1985 .{ }^{12}$ From the income register we also obtain information on whether or not the household in which the young adult grew up received means-tested social assistance in 2001. We interact a dummy variable for receipt of means-tested social assistance by the household with each of the parental education 
variables mentioned above. Thus, we obtain an indication of whether the parental households include adults with a long education but who are not able to support themselves through work. If there is such a family member, the young person could conclude that there are no significant economic benefits from such an education.

A substantial fraction of the young adults in our sample are foreign born or have foreign born parents. As there is a large variation among immigrants with respect to reasons for migration, education and attractiveness to potential employers - to some extent correlated with country of origin - we have defined eight different categories of immigrants based on country of birth (for details see the supplementary material). Table 1 shows a number of clear differences between categories of immigrants, on the one hand, and the native born on the other. For example, parental households with a background in the Middle East, sub-Saharan Africa and South and East Asia are strongly over-represented in the bottom quartile of the income distribution and a relatively large number have short education. Social assistance receipt is also widespread among such immigrants. For example, while 4 per cent of native households received social assistance in 2001 the corresponding proportion was 45 per cent among households originating from sub-Saharan Africa. The reason is twofold: Immigrants are not only more often unemployed than natives, unemployed immigrants are also less likely to have the work record required in order to receive unemployment insurance benefits. Employment rates among immigrants increases with length of time in Sweden (le Grand, Szulkin, Tibajev \& Tåhlin 2013). Immigrants and their children may perceive unemployment after a relatively short time in the country as more transitory and less demoralizing than unemployment of long duration. This is one of the reasons why we have distinguished between those young persons who at age 16 had lived six years or more in Sweden and those who had not. This is done for those whose parents were born in Southern Europe, the Middle East and North Africa, other Asian or African countries. Among those with parents born in other regions, the numbers who have lived in Sweden five years or less are too small for us to divide according to length of residence. ${ }^{13}$ The other reason is that having immigrated in late childhood or as a teenager would in itself tend make it more difficult to complete upper secondary school before age $21 .^{14}$

/Table 2 about here/ 
Table 2 shows the percentage of the 1985 cohort we study who lived in households receiving social assistance in 2001, divided according to the highest level of education in the household and the parents' country of birth. As can be seen, if the parents have post-secondary education and are born in Sweden or in Northern or Western countries, very few indeed of the households receive social assistance, whereas 20-35 per cent of the young persons whose well-educated parents were born in other parts of the world live in households that do. About 30 per cent of visible minority parents with post-secondary education acquired their highest educational level after moving to Sweden. ${ }^{15}$ As Table 2 shows, they are less often unemployed than those whose educational credentials were acquired prior to migration. Thus, limited transferability of education or statistical discrimination by employers uncertain about how to evaluate a foreign education plays a part. Yet Table 2 also shows a considerable difference between visible minorities with Swedish education and Swedish-born parents which may be due to direct labour market discrimination.

\section{Neighbourhood definition and characteristics}

The other set of explanatory variables we use in this study are defined at the neighbourhood level. We know in which neighbourhood the young person lived when aged 16. We apply a definition of "neighbourhood" which has been constructed for research purposes and is identical for the three regions studied. It has been used previously to map how residential segregation has evolved in metropolitan Sweden (National Board of Health and Welfare, 2010). By "neighbourhood" we understand an area smaller than a municipality, but larger than a city block and normally larger than a planning area. It often represents a natural social arena for its inhabitants where we might expect social interaction between inhabitants, particularly children and young adults, to take place. In our study a neighbourhood does not have to be identical to an administrative unit.

Thus, in this study, a neighbourhood is defined as a built-up area that:

- Corresponds to a city district or a residential area.

- Is demarcated by “natural borders" (large streets, green areas, etc.).

- Possesses a large enough number of inhabitants to provide a basis for certain private and public services.

- Can be considered as an "area of identification" by its inhabitants. 
The neighbourhoods usually have a population between 4000 and 10000 inhabitants (for details see Biterman, 2007). Closer inspections shows that some areas on the outskirts of the municipalities can best be considered as rural, or are sparsely populated (have fewer than 500 inhabitants of any age). As we expect social interaction to be of a different character in such areas, we have, as has been done in earlier studies using this data, excluded persons who lived in such locations from the analysis. In our study there are 273 neighbourhoods in the Stockholm metropolitan area, 138 in the Gothenburg metropolitan area and 93 in the Malmö metropolitan area.

The data we work with includes information on individuals of all ages in the three metropolitan areas and we know in which neighbourhood each person lives. Thus, for each neighbourhood, characteristics of its total population can be computed. Such characteristics include the level of education in the neighbourhood, the proportion of the population receiving unemployment insurance and/or social assistance and the proportion born in different countries.

/Figures 2-3 about here/

Figures 2 and 3 show that in certain underprivileged neighbourhoods the share living in households receiving social assistance is above 40 per cent. The share of the total population that has post-secondary education and live in households receiving social assistance is small but in a number of neighbourhoods, definitely not negligible, as seen in Figure 3 . Therefore, children who grow up in such neighbourhoods are likely to know, or know of, well-educated adults who are not established on the labour market.

\section{Young persons who have not graduated from upper secondary school}

/Table 3 about here/ 
In our data 17 per cent of young males and 14 per cent of young females have not graduated from secondary school at age 21 , as seen in Table 3 . The proportions are slightly lower for persons with a native background, and higher for almost all categories of persons with an immigrant background. The highest proportions that have not graduated from upper secondary school are observed among young men who, at age 16, have lived in Sweden less than six years and whose parents are from the Middle East and North Africa; from subSaharan Africa or Asia (46, 42 and 40 per cent, respectively). Among males who have immigrated earlier and among women, the percentage is lower, but still substantially above those for youngsters with Swedish-born parents. However, as persons with a native background are more numerous they nevertheless make up the majority (63 per cent) of all young adults who have not graduated from upper secondary school.

We investigate factors associated with not having graduated from upper secondary school by estimating logistic models and report the results for young men and young women in Table 4 . We report the coefficients and their standard errors as well as odds-ratios. ${ }^{16}$ Two specifications are applied, the first include characteristics of the parental household in 2001 (12 dummy variables indicating country of origin, in some cases divided by length of residence in Sweden), dummies for parental education, dummies indicating quartile of household income, one dummy indicating whether there was an adult male in the household, as well as a dummy indicating whether the household received social assistance. We also include interactions between parental education and receipt of social assistance. In the second specification we have added the proportion of all persons in the neighbourhood who have specific levels of education as well as variables measuring the proportion of adults in the neighbourhood who received social assistance and/or unemployment insurance divided according to whether they have or do not have post-secondary education. To permit more detailed patterns than a linear specification would, we have modelled the share receiving such transfers and having post-secondary education as a third-degree polynomial. We also included the share of visible minorities in the neighbourhood. ${ }^{17}$

/Table 4 about here/ 
When we only control for characteristics of the parental household (Model 1) many coefficients for parents birth-country are insignificant and the odds-ratios considerably smaller than what the overrepresentation shown in Table 3 would indicate. When we also control for neighbourhood characteristics, only a single coefficient is significantly positive and that is for a group that may not have lived in Sweden long enough to "catch up" by the age of 21. Thus it appears that characteristics correlated with immigrant background, play a far greater role than the background in itself.

Consistent with what has been reported from a very large number of studies in many countries, the level of parental education and the education of their offspring are positively related, in both specifications. We also find that parental household income in the upper half of the distribution is associated with a significantly lower risk of not having graduated from upper secondary school than an income in the lowest quartile for both genders. When there is no adult male in the household the odds ratio that a teenager will not graduate from secondary school is approximately 1.4 among young men, and 1.3 among young females. We find oddsratios significantly larger than 1 in case parents receive social assistance and the coefficient is largest when social assistance is received by a parent with post-secondary education.

In order to illustrate how the presence of adults in the parental home who are not able to support themselves from gainful employment is related to not having completed upper secondary school, Table 5 shows predicted probabilities according to gender, parental education and parental receipt of social assistance. It indicates that if the parental household receives social assistance, even though an adult member has a long education, the probability that the young adult does not complete upper secondary education is about as high as if the parent had only primary education and did not receive social assistance.

A young person may be discouraged by knowing, or being told, about people in the neighbourhood whose long education did not give them a foothold in the labour market. In Model 2, the coefficients for the percentage of persons in the neighbourhood with postsecondary education who receive social assistance or unemployment insurance, together with its square and cube, reflect the difference the proportion of such persons makes. They have the expected signs (positive for the linear and cubic terms, negative for the quadratic) and except for the cubic term in the male equation, they are all statistically significant. Note that the coefficient for percentage who have secondary or less education and receive 
unemployment insurance or social assistance has the opposite sign - it is negative and significant,

Since the persons most at risk of not finding work despite a long education are immigrants, in particular recent immigrants, the percentage unemployed with post-secondary education is correlated with the share of visible minorities in the neighbourhood. Analysis and discussion of whether and why the share of visible minorities could affect the probability that young persons do not complete secondary school would be a separate topic of research and falls outside the scope of this paper. We only note two things: First, that a concentration of visible minorities is significantly associated with a higher share of children not completing secondary school. On average, the estimated marginal effect of a 1 percentage point larger share of visible minorities is a 0.2 percentage point higher share of young people who have not completed secondary school. ${ }^{18}$ Second, we find that including this in the model does not alter the estimated impact of the share of unemployed with post-secondary education. Thus, our result is not a spurious result of omitting a possible confounding factor, the concentration of immigrants.

/Figure 4 and 5 about here/

With a third-degree polynomial, interpretation of the coefficients and odds-ratios is not entirely straightforward. Therefore we have made predictions from the model. These are shown in Figures 4 and 5 to illustrate how the probability of not having completed secondary school varies with the share of adults with a long education that cannot maintain themselves through work, as is indicated by receipt of social assistance or unemployment insurance. For each gender we have calculated the predicted probabilities for persons with characteristics associated with low, medium and high probability of not completing upper secondary education at age 21 . For both young men and young women, a higher share of unemployed persons with higher education in the neighbourhood is associated with an increased risk of not completing upper secondary school. For "Individuals C" with other characteristics associated with a low risk, the graph is rather flat, particularly for young men, and well below the other two. Thus, these other characteristics are more important than the variable we focus on. 
But for "Individuals B", with other characteristics associated with a medium risk of not completing upper secondary school it is otherwise, and even more so for the high-risk "Individuals A". An increase in the share of adults with a long education that cannot maintain themselves in the neighbourhood from 0 to about 4 per cent is associated with a sharp increase in risk. At higher levels the slope of the graphs is still positive but small, up to a turning point where it increases again. For young women, the coefficient for the cubic term is significant and there is a clear increase in the slope when the share reaches about 8 per cent. For young men, the cubic term is not significant and there is only a small upturn more or less at the highest share observed in any neighbourhood, 11 per cent who are highly educated and in households receiving social assistance or unemployment insurance. The interpretation of the square term should be rather straightforward, while that of the cube is less clear. The significant upturn found for women may indicate some kind of threshold effect: Once the share of unemployed highly educated in the neighbourhood pass that threshold the negative effects on motivation for pursuing upper secondary education are enhanced.

The figures illustrate that under favourable conditions the probability of not having completed upper secondary school is close to zero. In contrast, under the most unfavourable conditions the predicted probabilities of not having completed upper secondary school are well over 60 per cent for young females and over 50 per cent for young males. We have thus found support for the hypothesis that the existence of potentially discouraging examples, relevant adults that despite a long education cannot earn a living themselves, is linked to young adults not completing upper secondary education. A larger percentage who have less education and receive unemployment insurance or social assistance is actually associated with a higher possibility of completing secondary school.

A fundamental problem in studies of relations between parental as well as neighbourhood characteristics and individual outcomes is to determine whether the relations are causal when non-experimental data are used. We recognise that households where parents have tertiary education but are nevertheless unemployed may also have other social or psychological characteristics that influence the school achievements of the children. (We do, however, control for birth-regions outside Europe which are the most important predictors.) In the case of neighbourhood effects there is a long-standing discussion of endogenity or self-selection 
problems (Manski, 1993 Durlauf, 2004). As concerns this study we consider the risk of such bias to be much smaller for the neighbourhood characteristics than for the parental. It is not impossible that families whose children - for non-observed reasons - are more likely not to complete upper secondary school are also more likely to select, or be selected, into, or be less able to select out of neighbourhoods with high levels of unemployment. Yet, we do not see why they would select into neighbourhoods where specifically highly educated persons are unemployed and - apparently - not into those with many unemployed who have short education. Since we have controlled for the possible confounding factor of share of visible minorities (which is correlated with our prime explanatory variable), it is hard to see how selection into neighbourhoods could result in estimated effects of the proportions unemployed with long education and of the proportions unemployed with short education which not only differ in size but go in opposite directions.

\section{Conclusions}

This paper has examined factors associated with whether persons who were born in 1985 and grew up in metropolitan Sweden had graduated from upper secondary school when aged 21. For this generation, not having completed upper secondary school is generally seen as entailing a risk of being socially excluded. Among persons belonging to the cohort studied, 17 per cent of the males and 14 per cent of the females had not completed upper secondary school. We claimed that in order to understand why some young adults had not graduated from upper secondary school it can be fruitful to focus on the labour market failure of adults, relevant for the young person. Seeing adults who have acquired a long education but do not appear to reap any material benefit from it may discourage teenagers from investing time and effort in getting a long education themselves. Family members and persons in the neighbourhood where the young person grew up can be such relevant adults.

In order to examine the explanatory power of this hypothesis we analysed the probability of not having graduated from upper secondary school at age 21 by estimating logistic equations. The explanatory variables included several characteristics of the parental household, among them whether it received social assistance even though a parent had more than secondary education. It also included the proportion of adults in the neighbourhood with a postsecondary education, who nevertheless received unemployment benefits or social assistance 
Our estimates confirmed the existence of a statistical relationship between, on the one hand, parents with low education, relatively low household income and the absence of an adult male in the household where the young person grew up and on the other hand not having graduated from upper secondary school.

One main result is that if someone in the parental household had a post-secondary education but the household nevertheless received social assistance, the probability that the young person did not graduate from upper secondary school was substantially larger. The other main result is that the probability that the young person did not graduate from upper secondary school increased substantially with the proportion of adult persons with a post-secondary education that receive unemployment benefits or social assistance in the neighbourhood. The results also indicate that the high rates of not having graduated from upper secondary school that were recorded among many categories of children of immigrants are linked to labour market exclusion among adults who could otherwise have been positive examples of the value of education, not to the immigrant background per se.

What we have shown are statistically significant associations between on one hand, the labour market failure among longer educated parents and neighbours and young people who have not completed secondary school, on the other. Such a relation is consistent with findings from qualitative research as cited in the introduction, but is not necessarily causal. There is therefore room for more research related to our research questions. Such research could be pursued along different lines. One is to identify a natural experiment and evaluate its consequence. Another can be to use the kind of register data we use, but apply another statistical strategy. ${ }^{19}$ It would also be of interest to investigate to what extent not completing upper secondary is related to grades from or non-completion of compulsory school, and whether achievement in compulsory school is also related to the variables we study for example similar to the analysis in Jackson et al (2007) Our results also indicate that there is also scope for further qualitative research and for surveys that combine socio-economic and neighbourhood conditions with data on attitudes as in Mickelson (1990).

If one does accept that the statistical relations we have found have at least a causal element an important insight follows: Important as they are, one cannot expect more and better skilled school personnel and physical resources or school management to be sufficient for reducing the high rates of young adults not having completed upper secondary school observed in 
some neighbourhoods. Such policies have to be combined with efficient labour market measures directed towards adults so that the young persons can observe more consistent evidence that investing in secondary education pays off. In general having a secondary education reduces the risk of being unemployed among foreign born living in Sweden, as has been shown in studies such as that of Duwander (2001). It is important that young adults be made aware of this but the information might be a more efficient influence on behaviour if they also learn it from the concrete examples of parents as well as persons in the neighbourhood. 


\section{References}

Ahmed, A. ( 2015) "Etnisk diskriminering - vad vet vi, vad behöver vi veta och vad kan vi göra?", Ekonomisk Debatt, 43, no 4, 18 - 28. .

Andersson, E. \& Malmberg, B. (2015). Contextual effects on educational attainment in individualised, scalable neighbourhoods: Differences across gender and social class. Urban Studies, 52, $2117-2133$.

Andersson, E. \& Subramanian, S.V. (2006). Explorations of neighbourhood and educational outcomes of young Swedes. Urban Studies, 43, 2013-2025.

Andersson, R. \& Magnusson Turner, L. (2014). Segregation, gentrification, and residualisation. From public housing to market-driven housing allocation in inner city Stockholm. International Journal of Housing Policy 14, 3 - 29.

Angelov, N., Johansson, P. \& Kennerberg, L. (2008). Välja fritt och välja rätt. Drivkrafter för rationella utbildningsval, Bilaga 8 till Långtidsutredningen 2008, Stockholm 2008.

Åslund, O, Edin, P-A, Fredriksson, O. \& Grönqvist, H. (2009). Peers, neighborhoods and immigrant student achievement - evidence from a placement policy, WP 2009:17, Uppsala University, Department of Economics.

Atkinson, A., Cantillon, B., Marlier, E. \& Nolan, B. (2002). Social indicators. The EU and social inclusion. Oxford: Oxford University Press.

Beach, D. \& Sernhede, O. (2011). From learning to labour to learning for marginality: School segregation and marginalisation in Swedish suburbs. British Journal of Sociology of Education, 32, 257-274.

Bengtsson, T., Lundh, C. \& Scott, K. (2005). From boom to bust: The economic integration of immigrants in post-war Sweden. In K.F. Zimmermann (Ed.), European migration. What do we know? (Chapter 2). Oxford: Oxford University Press.

Biterman, D. (Ed.) (2007). Social Report 2006. The national report on social conditions in Sweden. International Journal of Social Welfare, 16, Supplement 1.

Björklund, A., Clark, M.A., Edin, P-A., Fredriksson, P. \& Kreuger, A-B. (2006). The market comes to education in Sweden. An evaluation of Sweden's surprising school reforms. New York: Russell Sage.

Björklund, A. \& Jäntti, M. (2013). Country case study - Sweden. In S. Jenkins, A. Brandeloni, J. Micklewright \& B. Noland (Eds), The great recession and the distribution of household income (Chapter 6). Oxford: Oxford University Press.

Björklund, A. \& Salvanes, K. (2011). Education and family background: Mechanisms and policies. In E. Hanushek, S. Machin \& L. Woessmann (Eds), Handbook of the economics of education, volume 3 (Chapter 3). Amsterdam: North Holland. 
Böhlmark, A. (2009), Integration of Childhood Immigrants in the Short and Long Run Swedish Evidence. International Migration Review, 43, 387-409.

Brännström, L. (2008). Making their mark: The effects of neighbourhood and upper secondary school on educational achievement. European Sociological Review, 24, 463-478.

Bunar, N. (2010). Nyanlända och lärande: en forskningsöversikt om nyanlända elever i den svenska skolan. Stockholm: Vetenskapsrådet.

Bunar, N. (2011). Multicultural urban schools in Sweden and their communities: social predicaments: The power of stigma, and relational dilemmas. Urban Education, 46, 141-164.

Bygren, M. and Szulkin, R. (2010). Ethnic environment during childhood and the educational attainment of immigrant children in Sweden. Social Forces, 88, 1305-1330.

Duvander, A-Z (2010) "Do Country-Specefic Skills Lead to Improved Labor Market Positions? An Analysis of Unemployment and Labor Market Returns to Education Amng Immigrants in Sweden", Work and Occupations, 28, 200 - 233.

Durlauf, S. (2004). Neighbourhood effects. In J.V. Henderson \& J.F. Thisse (Eds), Handbook of regional and urban economics, volume 4. Amsterdam: North Holland.

Dustman, C and Frattini, T. (2011) "Immigration: The European Experience", Discussion Paper Series 20/11, Centre for Research and Analysis of Migration, Department of Economics, University College of London.

Entorf, H. \& Lauk, M. (2008). Peer effects, social multipliers and migrants at school: An international comparison. Journal of Ethnic and Migration Studies, 34, 633-654.

Erikson, R. \& Jonsson, J.O. (1993). Ursprung och utbildning: Social snedrekrytering till högre studier. Huvudbetänkande, Stockholm: Statens Offentliga Utredningar 1993: 85.

Frisell, T., Öberg, S., Kuja-Halkola, R. and Sjölander, A. (2005) "Sibling Comparison Design: Bias from Non-shared Confounders and Measurement Error", Epidemiology, 23 (1), 713 - 20.

Fritzell, J., Bacchus Hertzman, J., Bäckman, O., Borg, I., Ferrarini, T. \& Nelson, K. (2014). Sweden: Increasing income inequality and changing social relations. In B. Nolan et al. (Eds), Changing inequalities and social implications in rich countries. Thirty countries' experiences. Oxford: Oxford University Press.

Grönqvist, H. (2006). Ethnic enclaves and the attainment of immigrant children. European Sociological Review, 22, 369-382. 
Hällsten, M. \& Szulkin, R. (2009). Families, neighborhoods, and the future: The transition to adulthood of children of native and immigrant origin in Sweden, SULCIS WP 2009:9, SULCIS, Stockholm.

Hällsten, M. (2010). The structure of educational decision making and consequences for inequality, a Swedish test case. American Journal of Sociology, 116, 806-854.

Hedin, K., Clark, E., Lundholm, E. \& Malmberg, G. (2012). Neoliberalization of housing in Sweden: Gentrification, filtering, and social polarization. Annals of the Association of American Geographers, 102, 443-463.

Hertzberg, F. (2003) Gräsrotsbyråkrati och normativ svenskhet: hur arbetsförmedlare förstår en etniskt segregerad arbetsmarknad. Stockholm: Arbetslivsinstitutet.

Jackson, M., Eriksson, R., Goldthorpe, J. H. and Y., Meir (2007) Primary and Secondary Effects in Class Differentials in Educational Attainment. The Transition to A-Level Courses in England and Wales, Acta Sociologica, 50:3, pp 211-229

Jonsson, J. \& Szulkin, R. (2007). Ethnic segregation and educational outcomes in Swedish comprehensive schools, SULCIS WP 2007: 2, SULCIS, Stockholm.

le Grand, C., Szulkin, R., Tibajev, A. \& Tåhlin, M. (2013). Vid arbetslivets gränser. Sysselsättning, matchning, barriärer 1974-2010. Underlagsrapport nummer 12 till den parlamentariska socialförsäkringsutredningen. S 2010:04. Stockholm: Statens Offentliga Utredningar.

Lewin, L. (2014). Staten får inte abdikera - Om kommunaliseringen av den svenska skolan. Betänkande av Utredningen om skolans kommunalisering, Stockholm: SOU 2014: 5.

Lindahl, L. (2011). A comparison of family and neighborhood effects on grades, test scores, educational attainment and income - evidence from Sweden. The Journal of Economic Inequality, 9, 207-226.

Lindvall, L. (2009). Neighbourhoods, economic incentives and post compulsory "education choices”. Uppsala: Institute for Labour Market Policy Evaluation, Working Paper 2009: 11.

Manski, C.F. (1993). Identification of endogenous social effects: The reflection problem. Review of Economic Studies, 60, 531-542.

Mickelson, R.A. (1990). The attitude-achievement paradox among black adolescents. Sociology of Education, 63, 44-61.

National Board of Health and Welfare (2010). Social Rapport 2010. Stockholm: National Board of Health and Welfare.

Nordin, M. (2013). Immigrant school segregation in Sweden. Population Research and Policy Review, 32, 415-435. 
Ogbu, J.U. (1978). Minority education and caste: The American system in cross-cultural perspective. New York: Academic Press.

Organisation of Economic Co-operation and Development (OECD) (2008). Growing Unequal? Income Distribution and Poverty in OECD Countries. Paris: OECD.

Öst, J., Andersson, E. \& Malmberg, B. (2013). School choice and increasing performance difference: A counterfactual approach. Urban Studies, 50, 407-425.

Sacerdote, B. (2010). Peer effects in education: How might they work, how big are they and how much do we know thus far? In E. Hanushek, S. Machin \& L. Woessmann (Eds), Handbook of the economics of education, volume 3 (Chapter 4). Amsterdam: North Holland.

Salikutluk, Z. (2013) Immigrants' Aspiration Paradox. Theoretical Explanations and Determinants of the Aspiration Gap between Native and Immigrant Students, MZES Working Paper 2013:150, Mannheim.

Sanbonmatsu, L., Kling, J. R., Duncan, G. J., \& Brooks-Gunn, J. (2006). Neighborhoods and academic achievement results from the Moving to Opportunity experiment. Journal of Human Resources, 41, 649-691.

Statistics Sweden (2011). Longitudinell integrationsdatabas för Sjukförsäkrings- och Arbetsmarknadsstudier (LISA) 1990-2009 (Integrated database for labour market research) Series Background Facts Labour and Education Statistics 2011: 4. Örebro.

Sykes, B. \& Kuyper, H. (2009). Neighbourhood Effects on Youth Educational Achievement in the Netherlands: Can Effects Be Identified and Do They Vary by Student Background Characteristics?, Environment and Planning, 41, 2417 -2436

Vartanian and Buck (2005) "Childhood and Adolescent Meighbourhood Effect on Adult Income: Using Siblings to Examine Differences in Ordinary Least Squares and Fixed Effect Models", Social Service Review, 79 (1) 60 - 96.

Vlachos, J. (2011). Friskolor i förändring. In L. Hartman (Ed.), Konkurrensens konsekvenser. Vad händer med svensk välfärd?. Stockholm: SNS förlag.

Wacquant, L. (2008). Urban outcast. A comparative sociology of advanced marginality. Cambridge: Policy Press.

Widgison, M. (2013). Från miljonprogram till högskoleprogram. Plats, agentskap och villkorad valfrihet. Gothenburg University, PhD Dissertation (sociology). 


\section{Table 1}

Characteristics of households and neighbourhoods of individuals born in 1985 who lived in metropolitan Sweden in $2001(\%)$.

\begin{tabular}{|c|c|c|c|c|c|c|c|c|c|c|}
\hline & All & $\begin{array}{l}\text { Swede } \\
\text { n }\end{array}$ & $\begin{array}{l}\text { No } \\
\text { rdi } \\
\text { c }\end{array}$ & $\begin{array}{l}\text { W- } \\
\text { Euro } \\
\text { pe }\end{array}$ & $\begin{array}{l}\text { N. } \\
\text { E. } \\
\text { Euro } \\
\text { pe }\end{array}$ & $\begin{array}{l}\text { S. } \\
\text { Europe }\end{array}$ & $\begin{array}{l}\text { ME } \\
\text { NA }\end{array}$ & $\begin{array}{l}\text { Lati } \\
\mathrm{n} \\
\text { Ame } \\
\text { rica }\end{array}$ & $\begin{array}{l}\text { sub- } \\
\text { Sahar } \\
\text { Afr. }\end{array}$ & $\begin{array}{l}\text { S. and } \\
\text { E. } \\
\text { Asia }\end{array}$ \\
\hline \multicolumn{11}{|l|}{ Household Characteristics } \\
\hline \multicolumn{11}{|l|}{ Education: } \\
\hline Primary or less & 12 & 8 & 19 & 23 & 10 & 21 & 31 & 24 & 27 & 31 \\
\hline Secondary & 39 & 39 & 50 & 37 & 40 & 48 & 34 & 47 & 41 & 33 \\
\hline Post-secondary & 47 & 53 & 30 & 36 & 48 & 27 & 29 & 28 & 23 & 32 \\
\hline No info & 1 & 0 & 2 & 3 & 2 & 4 & 6 & 2 & 10 & 5 \\
\hline \multicolumn{11}{|l|}{ Income quartile: } \\
\hline Quartile 1 & 24 & 14 & 20 & 35 & 31 & 50 & 68 & 35 & 64 & 64 \\
\hline Quartile 2 & 19 & 18 & 26 & 23 & 27 & 24 & 17 & 36 & 20 & 17 \\
\hline Quartile 3 & 23 & 26 & 27 & 18 & 21 & 17 & 9 & 17 & 12 & 12 \\
\hline Quartile 4 & 34 & 42 & 28 & 23 & 22 & 9 & 5 & 12 & 4 & 7 \\
\hline No father & 27 & 24 & 56 & 42 & 52 & 28 & 22 & 49 & 46 & 31 \\
\hline Receipt of social assistance & 10 & 4 & 9 & 10 & 13 & 30 & 39 & 22 & 45 & 32 \\
\hline \multicolumn{11}{|c|}{ Social assistance receipt and education: } \\
\hline Primary or less & 3 & 1 & 3 & 5 & 4 & 9 & 15 & 7 & 16 & 12 \\
\hline Secondary & 4 & 2 & 4 & 2 & 6 & 12 & 11 & 9 & 14 & 8 \\
\hline Post-secondary & 2.2 & 0.6 & 1 & 2 & 2.7 & 7.4 & 9.7 & 5.5 & 8 & 8.3 \\
\hline No info & 0.8 & 0 & 0.5 & 0.7 & 0.8 & 2 & 4.1 & 0.3 & 7.6 & 3.5 \\
\hline \multicolumn{11}{|l|}{ Percentage in neighbourhood: } \\
\hline With primary or less educ. & 18 & 17 & 20 & 19 & 19 & 25 & 25 & 23 & 26 & 23 \\
\hline With secondary educ. & 44 & 44 & 46 & 43 & 44 & 45 & 44 & 45 & 43 & 44 \\
\hline With post-secondary educ. & 35 & 37 & 31 & 35 & 34 & 25 & 26 & 28 & 26 & 29 \\
\hline No education info & 2 & 0 & 0 & 0 & 0 & 0 & 0 & 0 & 0 & 0 \\
\hline $\begin{array}{l}\text { Adults on unemployment } \\
\text { benefits or social assistance }\end{array}$ & 14 & 11 & 14 & 15 & 17 & 27 & 24 & 20 & 27 & 23 \\
\hline $\begin{array}{l}\text { Adults on UI or SA and } \\
\text { having primary educ. }\end{array}$ & 4 & 3 & 4 & 4 & 5 & 9 & 8 & 6 & 9 & 7 \\
\hline $\begin{array}{l}\text { Adults on UI or SA and } \\
\text { having secondary educ. }\end{array}$ & 6 & 5 & 7 & 7 & 8 & 12 & 10 & 8 & 11 & 10 \\
\hline $\begin{array}{l}\text { Adults on UI or SA and } \\
\text { post-secondary educ }\end{array}$ & 3 & 3 & 3 & 3 & 4 & 5 & 4 & 4 & 5 & 4 \\
\hline $\begin{array}{l}\text { Adults on UI or SA and no } \\
\text { educ info }\end{array}$ & 1 & 0 & 1 & 1 & 1 & 2 & 2 & 2 & 3 & 2 \\
\hline Visible minorities & 11 & 7 & 13 & 14 & 14 & 22 & 25 & 21 & 28 & 21 \\
\hline $\mathbf{N}$ & 30514 & 22731 & 923 & 296 & 631 & 1196 & 2906 & 581 & 626 & 624 \\
\hline
\end{tabular}

Notes: * Income quartile refers to all Swedish households including a person born in 1985 .

$* * \mathrm{HH}=$ parental household, $\mathrm{SA}=$ receipt of social assistance, $\mathrm{UI}=$ receipt of unemployment insurance. 
Table 2 The percentage of persons born in 1985 who lived in households receiving social assistance in 2001, according to background and educational level (acquired in Sweden or abroad).

\begin{tabular}{lrrrr}
\hline & $\begin{array}{l}\text { All } \\
\text { educational } \\
\text { levels }\end{array}$ & $\begin{array}{l}\text { Compulsory } \\
\text { education }\end{array}$ & $\begin{array}{l}\text { Secondary } \\
\text { education }\end{array}$ & $\begin{array}{l}\text { Post- } \\
\text { secondary } \\
\text { education }\end{array}$ \\
\hline All & 10 & 28 & 10 & 5 \\
Majority & 4 & 15 & 6 & 1 \\
$\begin{array}{l}\text { Visible minorities } \\
\text { of which with foreign education } \\
\text { of which with education } \\
\text { acquired in Sweden }\end{array}$ & 35 & 44 & 28 & 30 \\
\hline
\end{tabular}

Table 3

Percentage share who have not completed secondary school at age 21 , by gender and country of origin. Individuals born in 1985 who lived in metropolitan Sweden in 2001.

\begin{tabular}{lcc}
\hline & Men & Women \\
\hline All & 17 & 14 \\
Sweden & 14 & 12 \\
Nordic countries & 21 & 20 \\
Western Europe & 22 & 14 \\
North-East Europe & 20 & 12 \\
Southern Europe longer stay in Sweden & 23 & 13 \\
Southern Europe shorter stay in Sweden & 29 & 27 \\
MENA longer stay in Sweden & 26 & 17 \\
MENA shorter stay in Sweden & 46 & 32 \\
Latin America & 28 & 25 \\
Other Africa longer stay in Sweden & 35 & 23 \\
Other Africa shorter stay in Sweden & 42 & 33 \\
Other Asia longer stay in Sweden & 18 & 7 \\
Other Asia shorter stay in Sweden & 40 & 28 \\
\hline
\end{tabular}

Notes: Shorter stay in Sweden indicates that the individual has been registered in Sweden for 5 years or less between birth and 16 years of age.

Longer stay in Sweden indicates that the individual has been registered in Sweden for 6 years or more between birth and 16 years of age. 


\section{Table 4}

Logistic regression estimating the risk of not having completed secondary education when 21 years old - men and women born in 1985.

\begin{tabular}{|c|c|c|c|c|c|c|c|c|c|c|c|c|c|c|c|c|}
\hline & $\begin{array}{l}\text { Men } \\
\text { Model 1 }\end{array}$ & & & & Model 2 & & & & $\begin{array}{l}\text { Women } \\
\text { Model } 1\end{array}$ & & & & Model 2 & & & \\
\hline & Coeff & Std & Sig & OR & Coeff & Std & Sig & OR & Coeff & Std & Sig & OR & Coeff & Std & Sig & $\mathbf{O R}$ \\
\hline Intercept & -1.62 & 0.07 & $<.0001$ & & -4.99 & 1.20 & $<.0001$ & & -1.62 & 0.07 & $<.0001$ & & -4.99 & 1.20 & $<.0001$ & \\
\hline \multicolumn{17}{|l|}{$\begin{array}{l}\text { Parents born } \text { in }^{\mathrm{a}} \text { : } \\
\text { Reference }\end{array}$} \\
\hline Nordic countries & 0.02 & 0.12 & 0.88 & 1.02 & -0.06 & 0.12 & 0.644 & 0.95 & 0.22 & 0.13 & 0.08 & 1.25 & 0.16 & 0.13 & 0.214 & 1.17 \\
\hline Western Europe & 0.08 & 0.2 & 0.69 & 1.08 & -0.03 & 0.21 & 0.892 & 0.97 & -0.25 & 0.26 & 0.33 & 0.78 & -0.31 & 0.26 & 0.232 & 0.73 \\
\hline North-East Europe & 0.09 & 0.15 & 0.55 & 1.09 & -0.01 & 0.15 & 0.924 & 0.99 & -0.34 & 0.18 & 0.06 & 0.72 & -0.45 & 0.18 & 0.012 & 0.64 \\
\hline Southern Europe short ${ }^{b}$ & -0.03 & 0.24 & 0.91 & 0.97 & -0.18 & 0.24 & 0.448 & 0.83 & -0.04 & 0.24 & 0.86 & 0.96 & -0.10 & 0.25 & 0.689 & 0.91 \\
\hline Southern Europe long ${ }^{c}$ & -0.05 & 0.11 & 0.64 & 0.95 & -0.21 & 0.12 & 0.071 & 0.81 & -0.46 & 0.14 & 0.00 & 0.63 & -0.59 & 0.15 & $<.0001$ & 0.55 \\
\hline MENA short & 0.61 & 0.14 & $<.0001$ & 1.85 & 0.39 & 0.15 & 0.008 & 1.48 & 0.15 & 0.16 & 0.35 & 1.16 & -0.05 & 0.16 & 0.735 & 0.95 \\
\hline MENA long & 0.05 & 0.08 & 0.56 & 1.05 & -0.18 & 0.09 & 0.036 & 0.83 & -0.3 & 0.1 & 0.00 & 0.74 & -0.49 & 0.10 & $<.0001$ & 0.61 \\
\hline Latin America & 0.23 & 0.14 & 0.10 & 1.26 & 0.00 & 0.14 & 0.985 & 1.00 & 0.3 & 0.15 & 0.04 & 1.35 & 0.11 & 0.15 & 0.476 & 1.11 \\
\hline Other Africa short & 0.62 & 0.24 & 0.01 & 1.86 & 0.30 & 0.24 & 0.220 & 1.35 & 0.26 & 0.25 & 0.31 & 1.29 & 0.04 & 0.26 & 0.876 & 1.04 \\
\hline Other Africa long & 0.33 & 0.15 & 0.03 & 1.39 & 0.06 & 0.15 & 0.721 & 1.06 & -0.1 & 0.17 & 0.57 & 0.91 & -0.30 & 0.18 & 0.089 & 0.74 \\
\hline Other Asia short & 0.50 & 0.24 & 0.04 & 1.64 & 0.32 & 0.25 & 0.197 & 1.37 & 0.03 & 0.27 & 0.91 & 1.03 & -0.09 & 0.28 & 0.742 & 0.91 \\
\hline Other Asia long & -0.4 & 0.18 & 0.02 & 0.67 & -0.57 & 0.18 & 0.002 & 0.57 & -1.26 & 0.27 & $<.0001$ & 0.28 & -1.40 & 0.27 & $<.0001$ & 0.25 \\
\hline \multicolumn{17}{|l|}{$\begin{array}{l}\text { Educational level in } \mathrm{HH}^{\mathrm{d}} \\
\text { Reference secondary }\end{array}$} \\
\hline Primary or less & 0.49 & 0.07 & $<.0001$ & 1.63 & 0.43 & 0.07 & $<.0001$ & 1.54 & 0.5 & 0.08 & $<.0001$ & 1.64 & 0.46 & 0.08 & $<.0001$ & 1.58 \\
\hline Post-secondary & -0.77 & 0.06 & $<.0001$ & 0.46 & -0.73 & 0.06 & $<.0001$ & 0.48 & -0.68 & 0.06 & $<.0001$ & 0.51 & -0.63 & 0.07 & $<.0001$ & 0.53 \\
\hline No education info & 0.88 & 0.23 & 0.00 & 2.41 & 0.83 & 0.23 & 0.000 & 2.28 & 0.24 & 0.27 & 0.37 & 1.27 & 0.27 & 0.27 & 0.301 & 1.32 \\
\hline \multicolumn{17}{|l|}{$\begin{array}{ll}\text { Household } & \text { income } \\
\text { quartile reference quartile } & \end{array}$} \\
\hline Quartile 2 & -0.08 & 0.06 & 0.19 & 0.92 & -0.08 & 0.07 & 0.210 & 0.92 & -0.08 & 0.07 & 0.25 & 0.92 & -0.09 & 0.07 & 0.189 & 0.91 \\
\hline Quartile 3 & -0.26 & 0.07 & 0.00 & 0.77 & -0.23 & 0.07 & 0.001 & 0.79 & -0.31 & 0.08 & $<.0001$ & 0.73 & -0.31 & 0.08 & $<.0001$ & 0.73 \\
\hline
\end{tabular}




\begin{tabular}{|c|c|c|c|c|c|c|c|c|c|c|c|c|c|c|c|c|}
\hline Quartile 4 & -0.54 & 0.07 & $<.0001$ & 0.59 & -0.47 & 0.07 & $<.0001$ & 0.62 & -0.49 & 0.08 & $<.0001$ & 0.61 & -0.45 & 0.08 & $<.0001$ & 0.64 \\
\hline No adult male in $\mathrm{HH}$ & 0.36 & 0.05 & $<.0001$ & 1.43 & 0.33 & 0.05 & $<.0001$ & 1.39 & $\mathbf{0 . 3 0}$ & 0.05 & $<.0001$ & 1.34 & 0.26 & 0.05 & $<.0001$ & 1.30 \\
\hline \multicolumn{17}{|l|}{$\begin{array}{l}\text { HH receives social } \\
\text { assistance }\end{array}$} \\
\hline \multicolumn{17}{|l|}{$\begin{array}{l}\text { Interactions } \mathbf{S A}^{\mathrm{f}} \text { and } \\
\text { educational level }\end{array}$} \\
\hline HH SA and primary ed & 0.42 & 0.11 & 0 & 1.53 & 0.44 & 0.11 & $<.0001$ & 1.56 & 0.52 & 0.12 & $<.0001$ & 1.68 & 0.54 & 0.12 & $<.0001$ & 1.72 \\
\hline HH SA and secondary ed & 0.65 & 0.10 & $<.0001$ & 1.92 & 0.64 & 0.10 & $<.0001$ & 1.91 & 0.89 & 0.1 & $<.0001$ & 2.43 & 0.87 & 0.11 & $<.0001$ & 2.40 \\
\hline HH SA and post-sec ed & 1.09 & 0.14 & $<.0001$ & 2.98 & 1.05 & 0.14 & $<.0001$ & 2.86 & 1.20 & 0.15 & $<.0001$ & 3.33 & 1.14 & 0.15 & $<.0001$ & 3.14 \\
\hline HH SA and no ed info & 0.07 & 0.30 & 0.82 & 1.07 & 0.05 & 0.30 & 0.877 & 1.05 & 0.76 & 0.32 & 0.02 & 2.13 & 0.71 & 0.32 & 0.029 & 2.03 \\
\hline \multicolumn{17}{|l|}{$\begin{array}{l}\text { Neighbourhood } \\
\text { characteristics } 2001^{\mathrm{g}}\end{array}$} \\
\hline \multicolumn{17}{|l|}{ Share with: } \\
\hline Secondary ed & & & & & 0.01 & 0.01 & 0.405 & 1.01 & & & & & 0.05 & 0.02 & 0.004 & 1.05 \\
\hline Post-secondary & & & & & -0.01 & 0.01 & 0.560 & 0.99 & & & & & 0.01 & 0.01 & 0.318 & 1.01 \\
\hline $\begin{array}{l}\text { SA or } \mathrm{UI}^{\mathrm{h}} \text { and secondary } \\
\text { or less education }\end{array}$ & & & & & -0.02 & 0.01 & 0.007 & 0.98 & & & & & -0.03 & 0.01 & 0.001 & 0.97 \\
\hline $\begin{array}{l}\text { SA or UI and post- } \\
\text { secondary education }\end{array}$ & & & & & 0.38 & 0.11 & 0.000 & 1.47 & & & & & 0.59 & 0.12 & $<.0001$ & 1.81 \\
\hline $\begin{array}{l}\text { SA or UI and post- } \\
\text { secondary education } \wedge \wedge 2\end{array}$ & & & & & -0.05 & 0.02 & 0.029 & 0.95 & & & & & -0.10 & 0.03 & 0.000 & 0.91 \\
\hline $\begin{array}{l}\text { SA or UI and post- } \\
\text { secondary education }{ }^{\wedge \wedge} 3\end{array}$ & & & & & 0.00 & 0.00 & 0.128 & 1.00 & & & & & 0.01 & 0.00 & 0.002 & 1.01 \\
\hline Share visible minorities & & & & & 0.01 & 0.01 & 0.043 & 1.01 & & & & & 0.01 & 0.01 & 0.033 & 1.01 \\
\hline$-2 \log L$ & $\begin{array}{r}13146.7 \\
51\end{array}$ & & & & $\begin{array}{r}13061.2 \\
0\end{array}$ & & & & $\begin{array}{r}11057.5 \\
84\end{array}$ & & & & $\begin{array}{r}11937.8 \\
6\end{array}$ & & & \\
\hline
\end{tabular}

Notes: ${ }^{\text {a }}$ The estimated model also includes the share of adults in the neighbourhood with no education information.

${ }^{\mathrm{b}}$ Short - "short residence in Sweden", i.e. less than six years.

${ }^{c}$ Long - "long residence in Sweden", i.e. six years or more.

${ }^{\mathrm{d}} \mathrm{HH}=$ parental household.

e "Income quartiles" are those for all households including a person born in 1985, in Sweden, 2001.

${ }^{\mathrm{f}} \mathrm{SA}=$ social assistance.

${ }^{\mathrm{g}}$ Information on the proportion with no educational information in the neighbourhood is included in the estimation as a control variable. But the proportion is very small..

${ }^{\mathrm{h}} \mathrm{UI}=$ unemployment insurance. 


\section{Table 5}

Predicted probability from logistic regression (Model 2) of not having completed secondary education at age 21 . Percent

\begin{tabular}{|c|c|c|c|c|c|c|}
\hline & \multicolumn{3}{|l|}{ Men } & \multicolumn{3}{|l|}{ Women } \\
\hline & $\begin{array}{l}\text { HH does } \\
\text { receive } \\
\text { assistance }\end{array}$ & $\begin{array}{r}\text { not } \\
\text { social }\end{array}$ & $\begin{array}{l}\text { HH receives } \\
\text { social assistance }\end{array}$ & $\begin{array}{l}\text { HH does } \\
\text { receive } \\
\text { assistance }\end{array}$ & $\begin{array}{r}\text { not } \\
\text { social }\end{array}$ & $\begin{array}{l}\text { HH receives } \\
\text { social assistance }\end{array}$ \\
\hline Primary or less & & 28 & 38 & & 23 & 34 \\
\hline Secondary & & 20 & 32 & & 16 & 31 \\
\hline Post-secondary & & 11 & 26 & & 9 & 24 \\
\hline
\end{tabular}

Note: For an individual with Swedish background $\mathrm{HH}$ income 3 quartile, two person $\mathrm{HH}$ and average neighbourhood variables. 
Figure 1

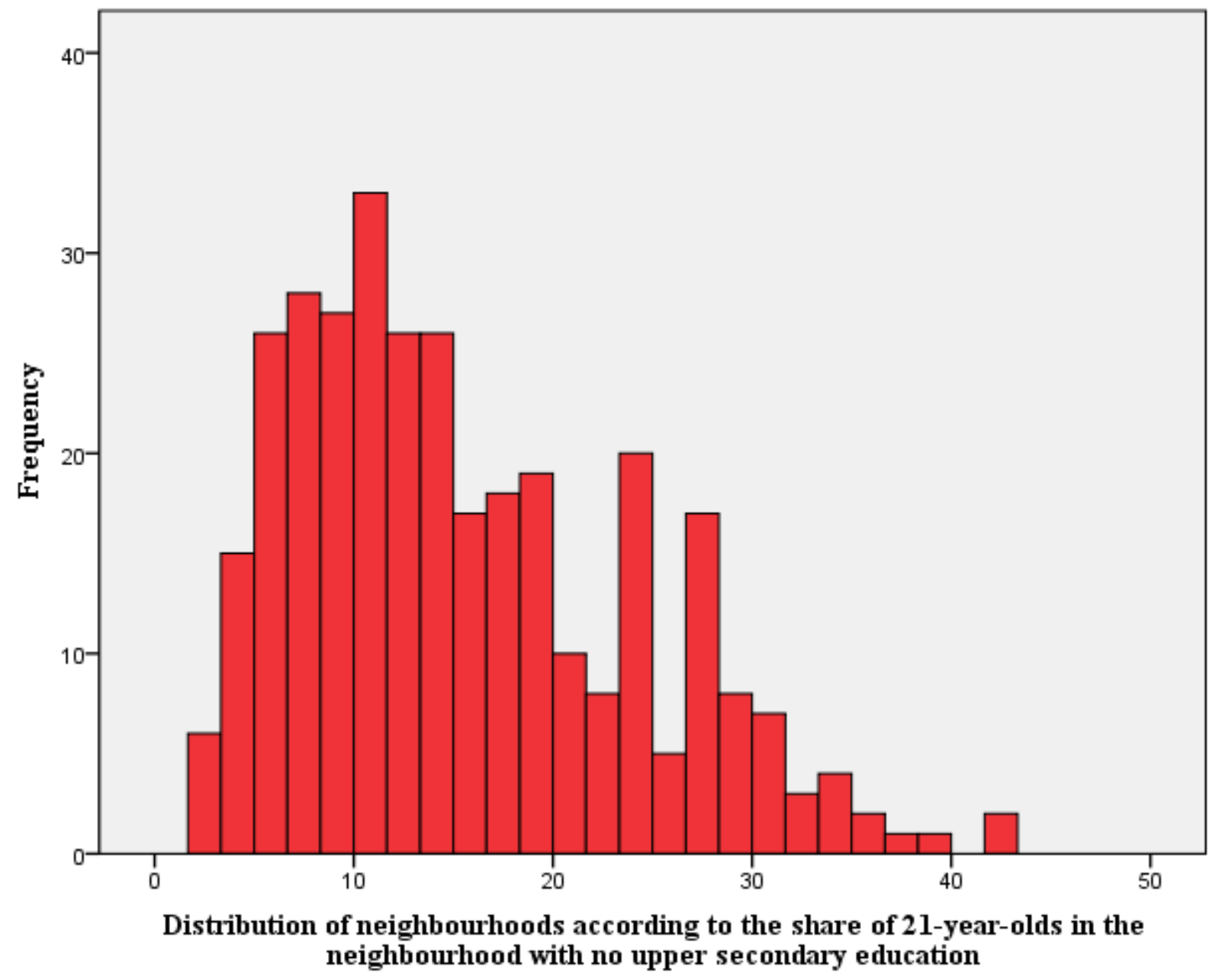


Figure 2

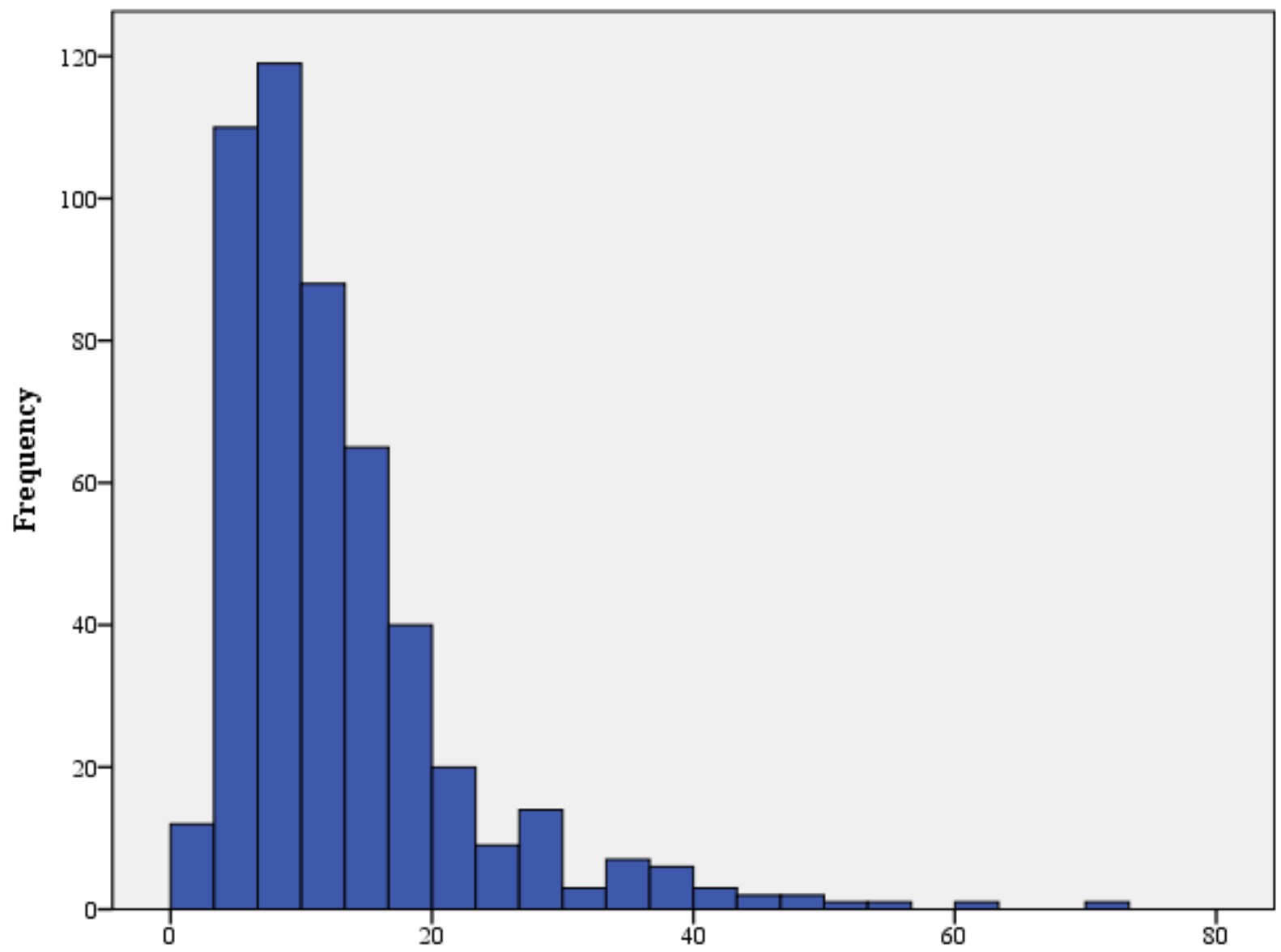

Distribution of neighbourhoods according to the share of households receiving social assistance and/or unemployment insurance 
Figure 3

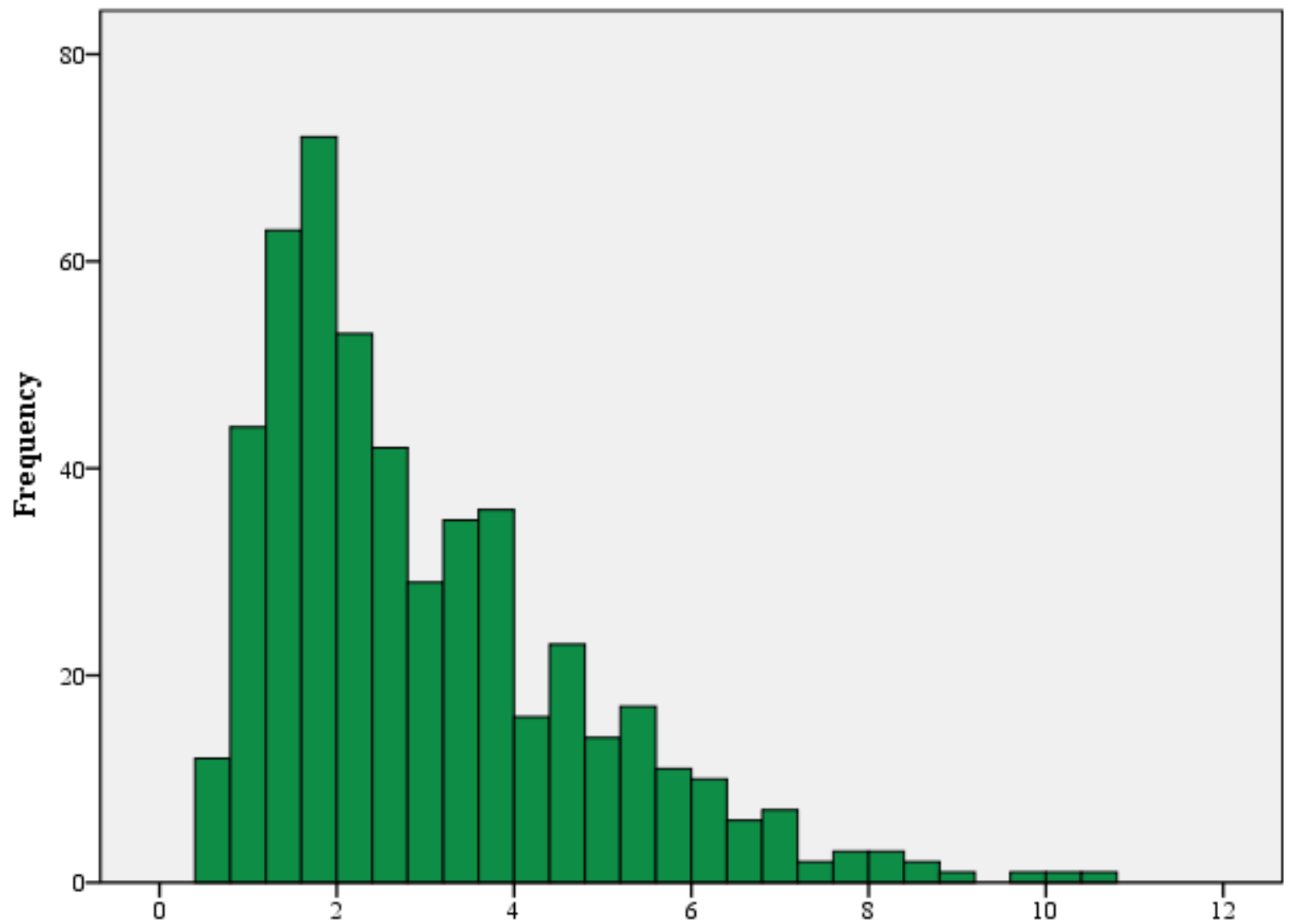

Distribution of neighbourhoods according to the share who have post-secondary education and also live in households receiving social assistance and/or unemployment insurance. 


\section{Figure 4}

Predicted probability of not finishing secondary education by number of highly educated unemployed in the neighbourhood - men born 1985.

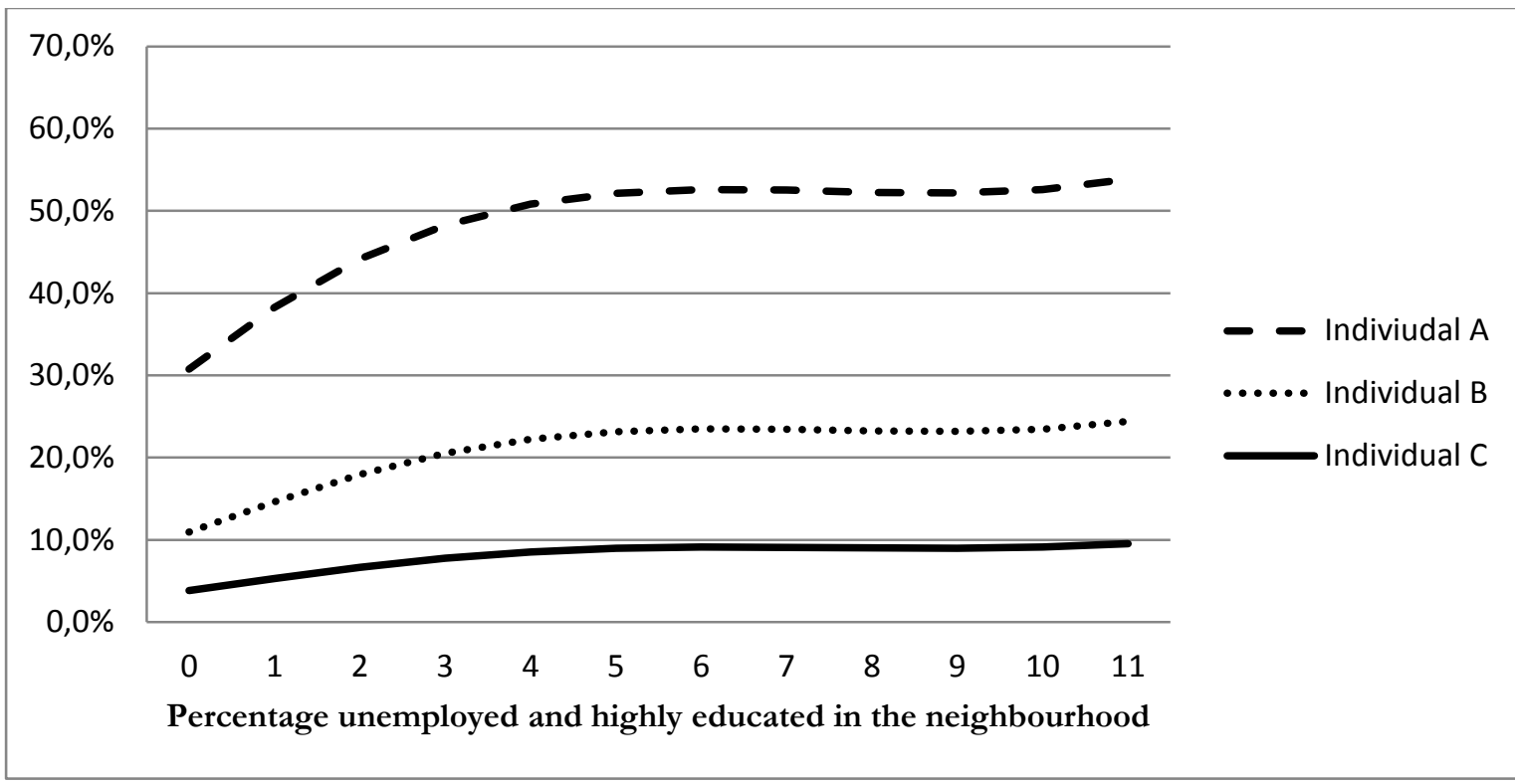

Notes:

A - Swedish background, primary education, disposable income, 1 quartile, no father, $\mathrm{HH}$ receiving SA and average neighbourhood variables.

B - Swedish background, HH secondary education, disposable income 2 quartiles, and average neighbourhood variables.

C - Swedish background, post-secondary education, disposable income 4 quartiles, and average neighbourhood variables. 


\section{Figure 5}

Predicted probability of not finishing secondary education by number of highly educated unemployed in the neighbourhood - women born 1985.

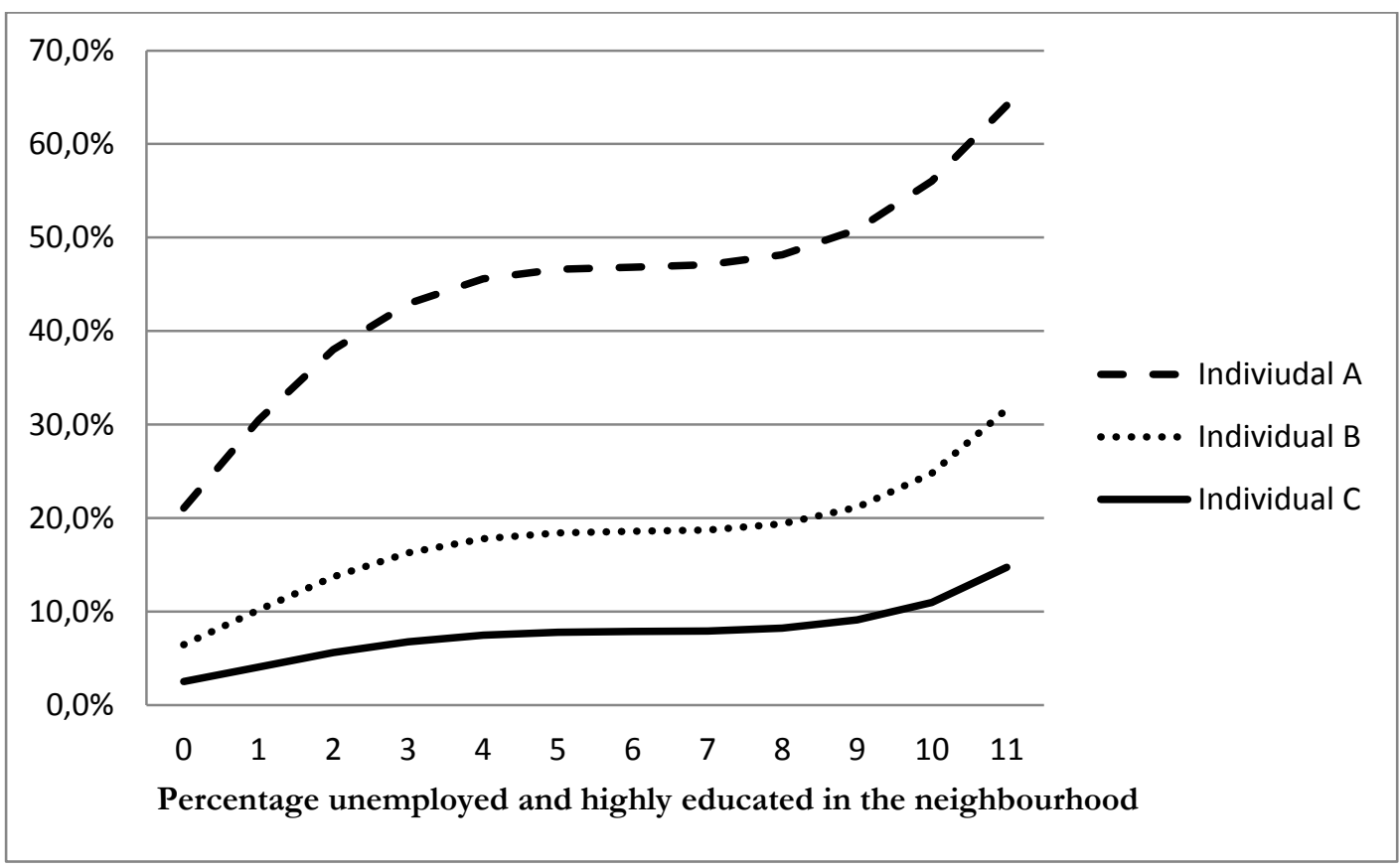

Notes:

A - Swedish background, primary education, disposable income, 1 quartile, no father, $\mathrm{HH}$ receiving SA and average neighbourhood variables.

B - Swedish background, HH secondary education, disposable income 2 quartiles, and average neighbourhood variables.

C - Swedish background, post-secondary education, disposable income 4 quartiles, and average neighbourhood variables. 
${ }^{1}$ Atkinson et al. (2002) proposed the proportion of those aged 18-24 who have only lower secondary education and are not in education and training leading to qualifications at least equivalent to upper secondary as a Level 1 indicator of social exclusion in the member states. Eurostat produces statistics for the member countries on "Early school leavers (per cent of population aged 18-24 who have at most lower secondary education and are not in further education and training", see http://ec.europa.eu/social/main.jsp?catId=756\&langId=en. According to this information Sweden belongs to the group of countries with the lowest proportion of early school leavers. For measures taken by the EU against youth unemployment see http://ec.europa.eu/social/main.jsp?catId=1036.

${ }^{2}$ Since this literature is well established and well-known, we refer the reader to the survey by Björklund and Salvanes (2011). Earlier studies on Sweden, more specifically, are surveyed by Erikson and Jonsson (1983).

${ }^{3}$ Recent Swedish examples include Angelov, Johansson \& Kennerberg (2008) and Hallsten (2010).

${ }^{4}$ See Sacerdote (2010), Entorf and Lauk (2008) and Nordin (2013) for surveys of such studies. Nordin's Swedish study looks at the relation between ethnic segregation at the school level and school grades as well as final level of education.

${ }^{5}$ See references in Sykes and Kuyper (2009).

${ }^{6}$ Their article also includes a review and discussion of the European literature in this area.

${ }^{7}$ See also Björklund, Clark, Edin, Fredriksson \& Kreuger (2006), Vlacos (2011) and Lewin (2014). Öst, Andersson \& Malmberg (2013) indicate that school choice has increased the between-schools-variation in grades.

${ }^{8}$ Dustman and Frattini (2011) show that the employment gap between immigrants and natives in Sweden is one of the largest found in high income countries.

${ }^{9}$ The literature on immigrants in the Swedish labour market is relatively large. Bengtsson, Lundh and Scott (2005) survey the literature and Ahmed (2015) studies using experiments and correspondence testing on discrimination in the labour and housing markets. 
${ }^{10}$ On changes in the income distribution in Sweden see OECD (2008), Björklund and Jäntti (2013) and Fritzell Bacchus Hertzman, Bäckman, Borg, Ferrarini and Nelson (2014). On changes in the housing policy see for example Hedin, Clark, Lundholm and Malmberg (2012) and Andersson and Magnusson Turner (2014).

${ }^{11}$ See for example Biterman (2007) and National Board of Health and Welfare (2010).

${ }^{12}$ The "parental household" includes the child, and the parent or parents, registered at the same address as the child. If the child lives with one parent and he/she is married or cohabitates and has a child with a new partner, the partner is also included. However, in case the parent of the child cohabitates with a partner with whom he/she does not have a child that person is not included and his/her income is not included in the household income. This is a limitation when we calculate household disposable income and when we observe whether there is an adult male in the household. For details on the equivalence scale used, see the documentation for the LISA database: http://www.scb.se/statistik/_publikationer/AM9901_1990I09_BR_AM76BR1104.pdf.

${ }^{13}$ A considerable number have moved in and out of the country more than once. Therefore we have added all the years in which they lived in Sweden, consecutive or not, rather than measuring years since latest immigration.

${ }^{14}$ For a survey of the literature see Bunar (2010). For example, Böhlmark (2009) finds that children who immigrated to Sweden after the age of nine years received lower grades when graduating from lower secondary school than those who immigrated when they were younger. When educational outcomes were measured at age 30 , age at immigration had small effects, however.

${ }^{15}$ We define "visible minorities" as persons born in, or with both parents born in, Africa. Asia, Latin America and South-East Europe

${ }^{16}$ Most of the covariates in our models are binary and for these we consider odds-ratios to have a more appealing intuitive interpretation than marginal effects calculated at sample mean.

17 The share of unemployed persons with post-secondary education in the neighbourhood is likely to be correlated with the share of visible minorities. In order not to confound an effect of simply living in a neighbourhood with a high concentration of immigrants and the variable we focus on, we included the proportion of visible minorities in the neighbourhood as a control variable in our estimates.

Another issue when assessing the importance of neighbourhood social environment is that of duration of "exposure" - for how much of their childhood and adolescence young persons have lived in a particular 
neighbourhood. As a sensitivity check, we re-estimated our models including only those in the 1985 birth cohort who had lived at least four years in the neighbourhood where they resided in 2001.

Some proportion of those who have not completed upper secondary school at age 21 might do so later - not least a proportion of those who settled in Sweden as children or adolescents. We found, however, that the share in the birth cohort of 1982 who completed upper secondary school when aged 21 to 22 years was only one per cent.

${ }^{18}$ For persons we define as having a high risk of not completing upper secondary education ("Individual A" as described in the notes to Figures 4 and 5), living in a neighbourhood with the largest observed share of visible minorities (57 per cent) the risk is up to 13 (for males) or 15 (for females) percentage points larger than if the share was the average for the sample, which is 11 per cent. For persons with characteristics associated with a low or medium risk, the share of visible minorities makes a far smaller difference.

${ }^{19}$ One alternative is to specify and estimate sibling models, The advantage of such an approach is that "within pair" estimates acquired through siblings comparisons are free from confounding from all factors that are shared by siblings. However, such an approach is not applicable when studying children who grow up without siblings and are also subject to several limitations, as discussed by for example Frisell et al (2012). Applying a siblings model approach will also inevitably reduce sample size and precision. It is thus an open question whether a siblings model approach would provide more correct answers to our research questions. On this see also Vartanian and Buck (2005). 